\title{
A CASE OF WERNER'S SYNDROME
}

\author{
L. IlLIS, B.Sc., M.B., B.S. \\ Academic Registrar, National Hospital for Nervous Diseases, Queen Square, London, W.C.1 \\ Formerly Senior House Officer, Neurological Unit, Brook Hospital, London, S.E.1 8
}

IN 1904 Werner described ' Cataract in connection with scleroderma' occurring in four brothers and sisters. The name 'Werner's syndrome' was attached to this disease complex by Oppenheimer and Kugel (1934) who reported the first postmortem findings in 1941. Many authors since then have emphasized that the skin changes are not those of true scleroderma (e.g. Thannhauser, 1945) and have described other features of the syndrome.

About 70 cases have been reported in the literature and from these a general picture of the disease emerges but with marked individual variation. The similarities of this syndrome to other diseases has been pointed out (Boyd and Grant, I959; Jacobsen, Rifkin and ZuckerFranklin, 1960).

\section{Werner's Syndrome}

Werner's syndrome as described in the literature is a familial disease with no definite racial preponderance, affecting males and females about equally. The age of presentation varies as does the age of first manifestation. Probably many cases are not diagnosed or the patients do not present themselves to doctors until complications are present.

These people are usually of short stature with slender limbs and a protuberant abdomen. They show features of premature ageing such as cataracts, early greying of the hair and baldness, arteriosclerosis and loss of teeth.

The skin shows scleroderma-like changes, e.g. atrophy of the subcutaneous tissues, a beaked nose and a bird-like appearance of the face, metastatic soft-tissue calcification and trophic ulcers about the ankles and feet.

Endocrine disorders are a feature of this disease: diabetes mellitus (Ellison and Pugh, 1955, and others), thinning of the eyebrows, scanty pubic and axillary hair (Jacobsen and others, 1960, and present case), and osteoporosis (Deuchar, 1956, and others). There is a marked incidence of neoplasia (Ellison and Pugh, r955; Jacobsen and others, 1960; Oppenheimer and Kugel, 194I).
In the two cases in which it has been reported the blood group is $\mathrm{A} \mathrm{Rh}+$ ve (Ellison and Pugh; I955, and the present case). In two cases (Deuchar $\vec{\omega}$ 1956, and the present case) the patients had claw? feet and absent ankle jerks. There is usually low 24-hour urinary ketosteroid and corti costeroid excretion (Bauer and Conn, 1953 Boyd and Grant, 1959; and present case) whiche rises on response to ACTH, though Ellison ando Pugh (1955) report figures of $4,725 \mathrm{mg} . / 24 \mathrm{hrs} N$ and $1.7 \mathrm{~g}$./litre for 17 -ketosteroid excretion in their two cases, and Waxman, Kelley and Motulsky (I96I) report that adrenal and probably pituitary function were within normal limits.

Occasionally urine chromatography shows thepresence of abnormal amounts of amino-acids o aspartic acid (Ellison and Pugh, 1955), taurige (Boyd and Grant, 1959). This last amino-aबेंक has been described by Lynas (1957) as occurring in dystrophia myotonica to which Werner's syndrome has some superficial resemblance.

\section{Case History}

Miss M. A., aged 42, single, of English parents who were unrelated, was referred to the Neurological Unit Brook Hospital, on account of slowly progressive weakness and numbness of the legs of about two years? duration, together with backache, and in recent weeks nocturia, precipitancy and occasional incontinence of urine.

Her childhood and early life were uneventful up te the age of 16 when her teeth began to decay and six were extracted; at this time she was developing de 3 formities of her toes and she described what was probably hallux valgus. At the age of 23 she was found to have pulmonary tuberculosis; at 24 all her teeth had been extracted, and at 26 her eyesight was failing and she had operations for bilateral cataracts. By this time. her hair was completely grey. At the age of 34 all her toes were amputated because of the severe deformities On several occasions she has had ulcers over theo malleoli and tendo achillis.

Her periods started at the age of 13 and the meno pause at 39 ; the menstrual flow was always scanty andk lasted from one to four days, occurring at irregulafo intervals from three to eight weeks.

There was not a strong family history: she had one brother who is healthy, married and with one child. On her mother's side there were two aunts who had thin hair at the ages of 45 and 60, and an uncle and and aunt with diabetes mellitus. 


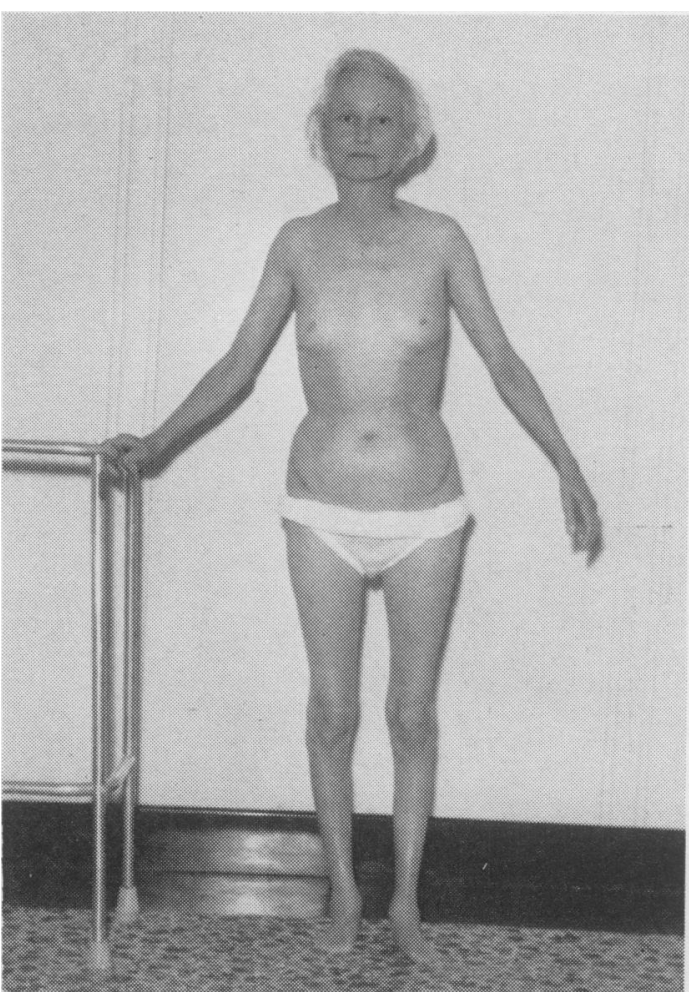

FIG. I.

On examination she was of small stature (height and span 57 in.), with a bird-like face, thin limbs, a protruberant abdomen (Fig. I) and cubitus valgus. She had very thin grey hair, thin eyebrows, very scanty pubic and axillary hair and small breasts. Possibly the skin showed loss of subcutaneous tissue and there were scars of healed ulcers about her ankles.

In the central nervous system the abnormal signs consisted of wasting of the left quadriceps and anterior tibial muscles and marked weakness of the legs. The knee jerks were present but the ankle jerks absent, and the plantar stimulation, although difficult to interpret due to the amputated toes, resulted in an extensor response in the feet on both sides and contraction of the hamstring muscles. There was impairment of sensation to the mid-calves.

In the cardiovascular system her blood pressure varied between $135 / 70$ and $155 / 80 \mathrm{~mm}$. $\mathrm{Hg}$ and there was an ejection systolic murmur at the left sternal edge.

Vaginal examination (under anæsthetic) showed an extremely hypoplastic uterus with a pin-point os. The ovaries were not palpable.

\section{Investigations}

Blood-group A Rh+ve, hæmoglobin $77 \%$, E.S.R. $28 \mathrm{~mm}$./hr.; W.B.C. 8,000, normal differential. Serum cholesterol $236 \mathrm{mg}$./100 ml., blood urea $23 \mathrm{mg}$./100 ml., urinary creatinine excretion $360 \mathrm{mg} . / 24$ hours. Radioactive thyroid function studies, glucose tolerance test, urinary examination, including chromatography, liver function tests and W.R. all normal. Serum protein and electrophoresis normal (total protein $7.7 \mathrm{~g}$. $/ 100 \mathrm{ml}$., albumin 4.0 g., globulin 3.7 g.). Serum calcium 9.7 mg./100 ml., phosphorus $5 \mathrm{mg}$., alkaline phosphatase
6.9 K.A. units. Serum and urinary sodium and potassium and urinary steroids are shown in Table $\mathbf{I}$. This shows the very low urinary ketosteroids and corticosteroids and their rapid rise in response to the exhibition of ACTH 20 units t.d.s. for three days. The urinary sodium was low and remained low until the ACTH was stopped when the level rose to normal. Follicle stimulating hormone (FSH) was measured in the urine. Before ACTH was given the test was positive to 96 mouse units and then fell to 24 mouse units; after three days of ACTH the test was negative (i.e. the level of FSH was now within normal limits).

The I 7-ketosteroids were determined by the method advocated by the Medical Research Council Committee (195I) and the corticosteroids by the method of Appleby, Gibson, Norymberski and Stubbs (1955).

$\mathrm{X}$-rays of the chest showed bilateral apical fibrosis with no evidence of active disease. There was calcification of the aorta, and soft tissue calcification in the left thumb, both elbows and both knees. There was doubtful osteoporosis.

Lumbar puncture: CSF protein 2 g./100 ml.; a myelogram demonstrated almost complete hold-up of the myodil column at the level D.II/I2 where there was a rounded filling defect. Below this were numerous irregular filling defects, suggesting an angiomatous malformation.

Chromosome studies on peripheral blood were carried out by Professor W. M. Davidson, of King's College Hospital, who reported them to be normal. The result on 32 chromosome counts was: chromosomes 42, 2; 43,$3 ; 44,0 ; 45,5 ; 46,21 ; 47,1$. On the five cells with a count of 45 , detailed karyotypes were done but no consistently missing chromosome was found.

\section{Operation}

A laminectomy at the level of $D_{11}$ and $D_{12}$ was carried out by Mr. G. B. Northcroft and a solid tumour of the spinal cord was removed together with an angiomatous malformation below it. She stood the general anæsthetic well; the post-operative course was uneventful and she has made a good recovery. The tumour was a hæmangio-lipoma with occasional mitotic figures. A muscle biopsy was normal and the skin was probably normal but with a doubtful increase in collagen.

\section{Discussion}

This patient presents most of the manifestations of Werner's syndrome described in the literature, although many reported features are not present in this case: e.g. abnormal aminoacid excretion (Ellison and Pugh, I955; Boyd and Grant, 1959); skin and muscle changes (Williams, 1949), diabetes mellitus (Ellison and Pugh, r955, and others) although there is a family history of diabetes.

There are, however, some interesting features in this case:

This woman has many features of Turner's syndrome, short stature, increased carrying angle, evidence of ovarian hypofunction, scanty pubic and axillary hair, irregular scanty menstruation, small breasts, hypoplastic uterus and small ovaries.

Strictly speaking, if webbing of the neck is absent, then a case otherwise fitting cannot be called Turner's syndrome, but is more precisely

\section{$\infty$} $\vec{\omega}$ (2) כ 及 < 


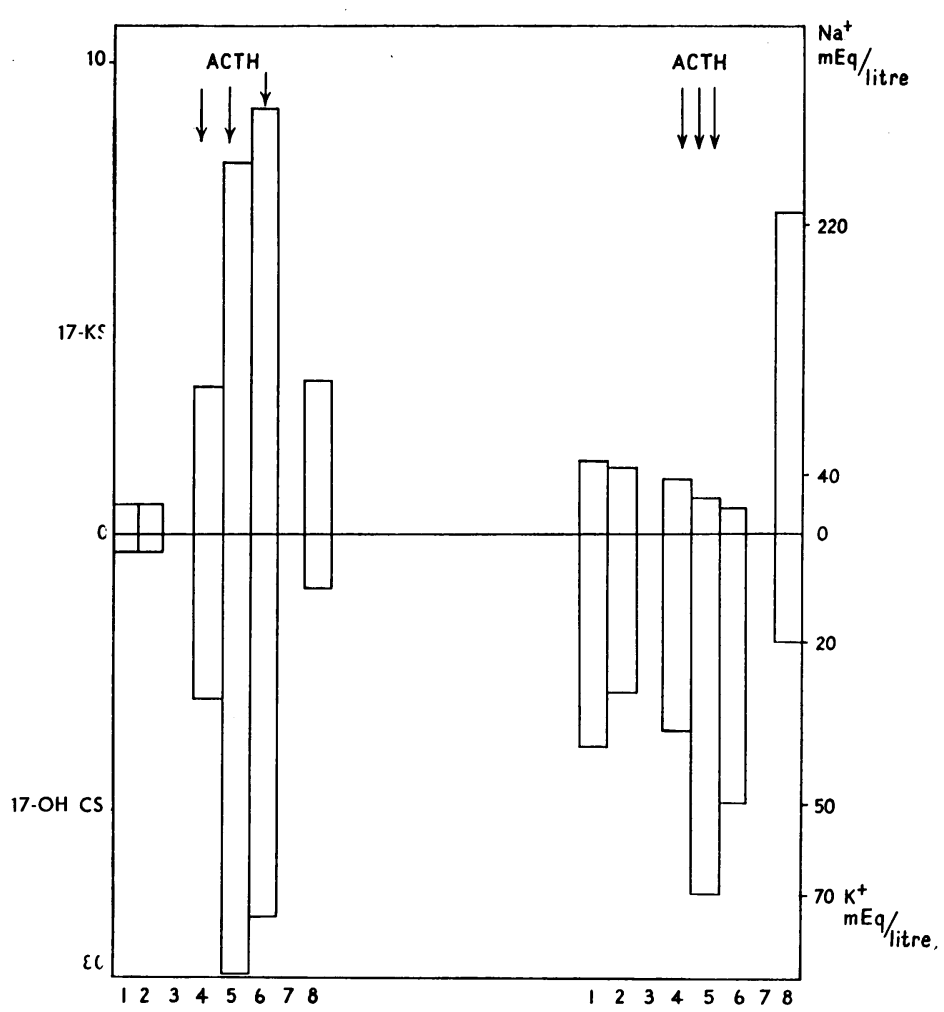

TABLE I

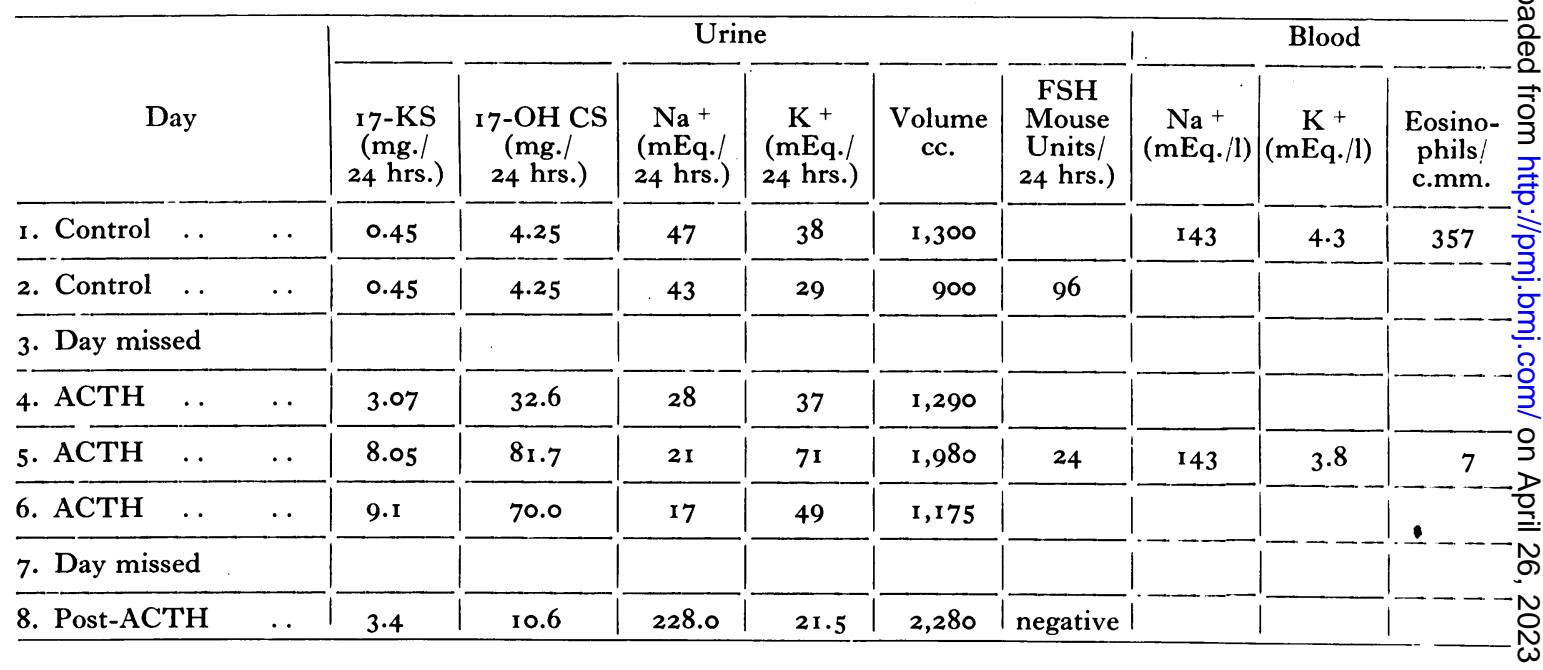

termed ovarian dysgenesis (Polani, 1961). In this connection it is interesting that the chromosomes are normal, and Motulsky (1962), Fraccaro, Bott and Calvert (1962) and Learner, Day, Weiss and DiGeorge (1962) have each also reported normal chromosomes on one patient.
Boyd and Grant (I959) suggested that cases of Werner's syndrome manifested pituitary and adrenal hypofunction. The present case hardly $\stackrel{\oplus}{\rightarrow}$ supports this contention (though the resting 0 excretion of 17 -ketosteroids was low and rose ${ }^{\circ}$

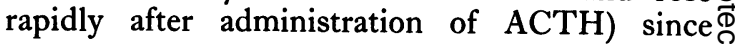


there was indirect evidence of normal TSH secretion and the increased urinary excretion of FSH was compatible with a normal pituitary response to ovarian deficiency (either primary or post-menopausal.)

As West (1961) showed no change in adrenocortical function with advancing age, the abnormalities in Werner's syndrome evidently cannot be explained merely in terms of somatic ageing but rather reflect the underlying cause which is probably a single defect of recessive inheritance (Waxman and others, I96I).

This woman presented with the signs and symptoms of a spinal tumour, and it is obvious from the literature that there is a tendency for cases of Werner's syndrome to develop neoplasms. This may be another manifestation of early ageing or a feature of the underlying cause.

Finally, it is clear from the literature that not all the cases described as Werner's syndrome fall into one homogeneous group; some, for instance, have no disturbance of steroid metabolism (Waxman and others, 196I), and some no evidence of 气 gonodal dysgenesis (e.g. Deuchar's patient had $\underset{\mathrm{D}}{3}$ had two children).

Many, including the case presented, have $c$ features of Turner's syndrome and it is probable that many cases of atypical Turner's syndrome are included in the Werner's group. Chromosome studies are obviously an essential part of the investigation of any suspected case of Werner's syndrome.

\section{Summary}

A case of Werner's syndrome is described, which has some features of Turner's syndrome but with a normal chromosome constitution.

This patient was admitted under the care of Dr. Raymond Hierons at the Brook Hospital and I would $\infty$ like to thank him and Dr. A. A. G. Lewis for their help and encouragement, and Dr. J. D. H. Slater for helpful comments.

\section{REFERENCES}

Appleby, J. I., Gibson, G., Norymberski, I. K., and StubBs, R. D. (1955): Indirect Analysis of Corticosteroids, Biochem. F., 60, 453.

Bauer, J. M., and ConN, J. W. (1953): Werner's Syndrome: A Study of Adrenocortical and Hepatic Steroidal Metabolism, Texas St. F. Med., 49, 316.

Boyd, M. W. J., and Grant, A. D. (I959): Werner's Syndrome (Progeria of the Adult), Brit. med. F., ii, 920.

Deuchar, D. C. (1956): Werner's Syndrome, Proc. roy. Soc. Med., 49, 316.

Ellison, D. J., and PUGH, D. W. (1955): Werner's Syndrome, Brit. med. F., ii, 237.

Fraccaro, M., BotT, M. G., and Calvert, H. T. (1962): Correspondence, Lancet, i, 536.

HubBLE, D. (I96I): The Endocrine Orchestra, Brit. med. F., i, 523.

Jacobsen, H. G., Rifkin, H., and Zucker-Franklin, D. (1960): Werner's Syndrome: A Clinical Roentgen Entity, Radiology, 74, 373 .

Learner, N., Day, H. J., Weiss, L., and DiGgorge, A. (1962): Correspondence, Lancet, i, 536.

Lynas, M. A. (1957): Dystrophia Myotonica with Special Reference to Northern Ireland, Ann. hum. Gen., $21,318$.

Medical Research Council Committee on Clinical Endocrinology (195I): Proposed Standard Method of I7-Ketosteroid Determination, Lancet, ii, 585 .

Motulsky, A. G., Schultz, A., and Priest, J. (1962): Correspondence, Ibid., i, i6o.

OPPENHEIMER, B. S., and KugeL, V. H. (1941): Werners' Syndrome: Report of First Necropsy and of Findings in New Case, Amer. F. med. Sci., 202, 629.

Polani, P. E. (196I): Sex Chromosome Aberrations, in 'Clinical Aspects of Genetics ', edit. F. Avery Jones. London: Pitman Medical.

Symington, T. (I959): The Human Adrenal Cortex in Disease, in 'Modern Trends in Pathology', edit. D. H. Collins. London: Butterworth.

Thannhauser, S. J. (1945): Werner's Syndrome (Progeria of the Adult) and Rothmund's Syndrome, Ann. intern. Med., 23, 559 .

Waxman, S. H., Kelley, V. C., and Motulsky, A. G. (1961): Adrenal Function Studies in Werner's Syndrome, Clin. Res., 9, 102.

WeRNER, C. W. O. (1904):- Uber Katarakt in Verbindung mit Sklerodermie. Inaugural Dissertation, Kiel. Schmidt and Klaunig.

West, C. D., Brown, H., Simons, E. L., Carter, D. B., Kumagai, L. F., and Englert, E. (196i): Adrenocortica] Function and Cortisol Metabolism in Old Age, Clin. Res., 9, 102.

Williams, D. I. (r949): Werner's Syndrome, Proc. roy. Soc. Med., 42, 572. 